\title{
PERFORMANCE ASSESSINGOF IMPACT AND ROTATING SPRINKLER BASED ON CATCH-CAN DATA
}

\author{
Zedan, A. M.* and Khedr, A. F.**
}

\begin{abstract}
The main objective of the present study is to evaluate two types of sprinklers (impact sprinkler and rotating sprinkler), impact sprinkler (average nominal discharge from 780 to $1660 \mathrm{l} / \mathrm{h}$ at operating pressure from 100 to $400 \mathrm{kPa}$ ) and rotating sprinkler (average nominal discharge from 360 to $730 \mathrm{l} / \mathrm{h}$ at operating pressure from 50 to $350 \mathrm{kPa}$ ) to determine optimum operating conditions that achieve high application uniformity. The coefficient of uniformity $(C U)$ and distribution uniformity (DU) were evaluated under different levels of operating pressure and constant riser height of $1.0 \mathrm{~m}$. It was concluded that the operating conditions that achieved high coefficient of uniformity and distribution uniformity was operating pressure of $200 \mathrm{kPa}$ for impact sprinkler. The results showed that the highest values of $C U$ and DU were $90.55 \%$ and $68.10 \%$ for impact sprinkler respectively while for rotating sprinkler with combination of trajectory angles $\left(20^{\circ}, 25^{\circ}\right)$, the corresponding values of $C U$ and DU were $85.60 \%$ and $60.50 \%$, respectively. Also, to achieve high percentage of overlap simulation model was used, it appeared that the spacing between sprinklers should be higher than or equal to $50 \%$ of wetted diameter to avoid water lose and minimize irrigation system cost.
\end{abstract}

\section{INTRODUCTION}

$\mathrm{P}$ ressurized irrigation systems are relatively modern techniques which have many advantages. Sprinkler irrigation is a relatively new method in Egypt especially in the newly reclaimed areas due to its high control of water distribution and suitability to most of soil and crop types. Also, sprinkler irrigation distributes water more uniformly than any other methods (El-Ansary et al., 2003).

\footnotetext{
*Lecturer of Agric. Eng., Agric. Eng. Dep., Fac. of Agric., Zagazig Univ., Egypt. **Lecturer of Agric. Eng., Agric. Eng. Dep., Fac. of Agric., Suez Canal Univ., Egypt.
} 
The uniformity of water application in a sprinkler irrigation system is an important and a central design goal classified the irrigation uniformity in solid set systems as "low" when the Christiansen's coefficient of uniformity was below $84.0 \%$, (Keller and Bliesner, 2000) indicated that there are several factors affect the water application efficiency of sprinkler irrigation system such as variation of individual sprinkler discharge throughout the lateral lines, variation in water distribution within the sprinkler spacing area, loss of water by direct evaporation from the spray and evaporation from the soil surface before.

Generally, if the distribution uniformity $(D U)$ is poor then some plants in a zone will be under watered and others will be over watered. Improperly watered plants will show poor growth and increased pest problems. Also dry or water logged media or soils will reduce fertilizer uptake by the plants. ITRC (1991) and Schwankl et al. (2003) suggested (DU) values as excellent $(75-85 \%)$, good $(65-75 \%)$ and poor $(50-65 \%)$. The upper, lower limits and middle values are for multi-stream, single-stream rotor and fixed-spray sprinkler respectively. Aboamera and Sourell (2003) attempted to achieve good water distribution for a new sprinkler nozzle called floppy sprinkler at an acceptable irrigation intensity. They found that the averaged Christiansen coefficient of uniformity $(C U)$ and distribution uniformity $(D U)$ was $88.01 \%$ and $80.94 \%$, respectively for the $8.0 \mathrm{~m}$ of sprinkler and lateral spacing at $1.5 \mathrm{~m}$ sprinkler height and 200 $\mathrm{kPa}$ operating pressure. Badr (1992) found that the distribution uniformity $(D U)$ values under fixed sprinkler irrigation system were increased from $69.0 \%$ to $94.6 \%$ for square pattern, from $53.0 \%$ to $83.90 \%$ for rectangular pattern and from $57.0 \%$ to $96.70 \%$ for triangular pattern at operating pressure of $250 \mathrm{kPa}$.

Ascough and Kiker (2002) studied the application uniformity of different irrigation systems in the sugar industry in five sugar-growing regions in South Africa. The average low-quarter distribution uniformity $(D U)$ values of center pivot, dragline, micro-irrigation, floppy and semi-permanent sprinkler systems were 81.40, 60.90, 72.70, 67.40 and $56.90 \%$, respectively. Amer (2006) found that high degree of water distribution 
uniformity optimal spacing between spinner sprinklers was found to be as $60 \%$ from diameter of throw in square layout and in range from 50 to 70 $\%$ from diameter of throw in triangular. For impact sprinklers, spacing was recommended to be as $50 \%$ from diameter of throw in square layout and in range from 50 to $60 \%$ in triangular. Triangular layout achieved higher uniformity than square even for the same served area. Available sprinkler devices have been increased dramatically in recent years, from the conventional single or double nozzle impact sprinkler with many types of nozzles to various types of deflection-plate sprinklers which influence the drop sizes and water distribution patterns over a wide range of flow rates and pressures (Kincaid et al., 1996).

A sprinkler water distribution pattern depends on many factors, such as sprinkler type, sprinkler spacing, nozzle diameter, angle and operating pressure (e.g., vane, flow control and shape). In field conditions, it also depends on the temperature, humidity and wind speed (Seginer et al., 1991). Tarjuelo et al. (1999b) found that uniformity increases by using jet-straightening vanes in the main nozzle, double nozzles under low wind speeds ( $\mathrm{W}<3 \mathrm{~m} \mathrm{~s}^{-1}$ ) and single nozzles under high wind speeds. Also, the highest irrigation uniformity was achieved when the sprinkler operated with double nozzle than with a single nozzle. Where winds are always very low, high-angle sprinkler give the best results with a minimum of pressure, (Keller and Bliesner, 2000). Also, they stated that many sprinkler manufacturers have compromised on a trajectory angle of between $22^{\circ}$ and $24^{\circ}$ to achieve reasonable performance under various wind conditions.

Awady and Gomaa (1996) stated that the lowest values of coefficient of uniformity occurred at low pressure and large sprinkler spacing. Optimum $(C U)$ of $76.0 \%$ resulted from square sprinkler spacing of $2.0 \mathrm{x}$ $2.0 \mathrm{~m}$ at pressure of $100 \mathrm{kPa}$, while the same sprinkler spacing at $50 \mathrm{kPa}$, optimum $(C U)$ was $70.0 \%$. Rectangular sprinkler spacing of $3.0 \times 2.0 \mathrm{~m}$ required pressure of $100 \mathrm{kPa}$ to give $(C U)$ of $75.0 \%$. Thus, there is a body of evidence that in agricultural systems soil moisture uniformity is generally higher than catch can values after sprinkler irrigation. 
However, there is only limited literature supporting this finding on turfgrass and bare soil. The Irrigation association has recommended $D U$ as a performance measure of sprinkler systems; however, this measurement index may not adequately represent conditions in the soil (Dukes et al., 2006).

To design an efficient sprinkler irrigation system, it is necessary to determine the optimum operating conditions that achieve high $C U, D U$ and excellent distribution efficiency, therefore the main objectives of the present study are to compare irrigation performance of impact sprinkler and rotating sprinkler, study the effect of operating pressure and combination of trajectory angles on distribution uniformity and simulate the experimental data to determine sprinkler spacing that achieves optimum water distribution.

\section{MATERIALS AND METHODS}

The experimental work was carried out at the research Farm, Faculty of Agriculture, Suez Canal University. The experimental sprinkler system consists of a $0.75 \mathrm{~kW}$ electric-centrifugal pump connected with a water tank which gives a steady flow of water. Two valves were fitted after the pump to control the flow rate reaching the sprinkler device. A manual pressure regulator (Model 100-PRV) was installed in series to regulate the supply pressure to the test unit of sprinkler system. Pressure gauge (up to $600 \mathrm{kPa}$ ) and flow meter were used to approximate the desired pressure at the sprinkler nozzle. An aluminum pipe has diameter of 19.05 $\mathrm{mm}$ was used to transmit water from pumping set to sprinkler device, twenty sprinklers were chosen at random sample from impact and rotating sprinkler were used in this study had an average nominal discharge from 780 to $1660 \mathrm{l} / \mathrm{h}$, coverage diameter $11.0-16.50 \mathrm{~m}$ at operating pressure from 100 to $400 \mathrm{kPa}$ for impact sprinkler and average nominal discharge from 360 to $730 \mathrm{l} / \mathrm{h}$, coverage diameter $5.0-12.80 \mathrm{~m}$ at operating pressure from 50 to $350 \mathrm{kPa}$ for rotating sprinkler.

Two devices of impact and rotating sprinkler were installed as a permanent system. The unique sprinkler design is suitable for different 
installation options as required for the crops. The impact sprinkler and rotating sprinkler plastic material, $19.05 \mathrm{~mm}$ female thread sprinkler body, double nozzle is $4.8 \mathrm{~mm}$ and $2.6 \mathrm{~mm}$ diameter for impact sprinkler and diameter is $1.85 \mathrm{~mm}$ for rotating sprinkler and rotating full circle forming uniform droplets, were used in this study.

The catch cans were plastic containers with a $150 \mathrm{~mm}$ diameter and 85 $\mathrm{mm}$ height were located under sprinkler in an across the full circle of sprinkler within the range of the spray nozzles throw to collect the water. The catch cans were distributed according to (ASABE Standard, 2006). Spacing of collectors (catching cans) for radius of throw determination is given in Table (1) and Figure (1).

Table (1): Spacing of collectors according to ASABE S398.1, 2006.

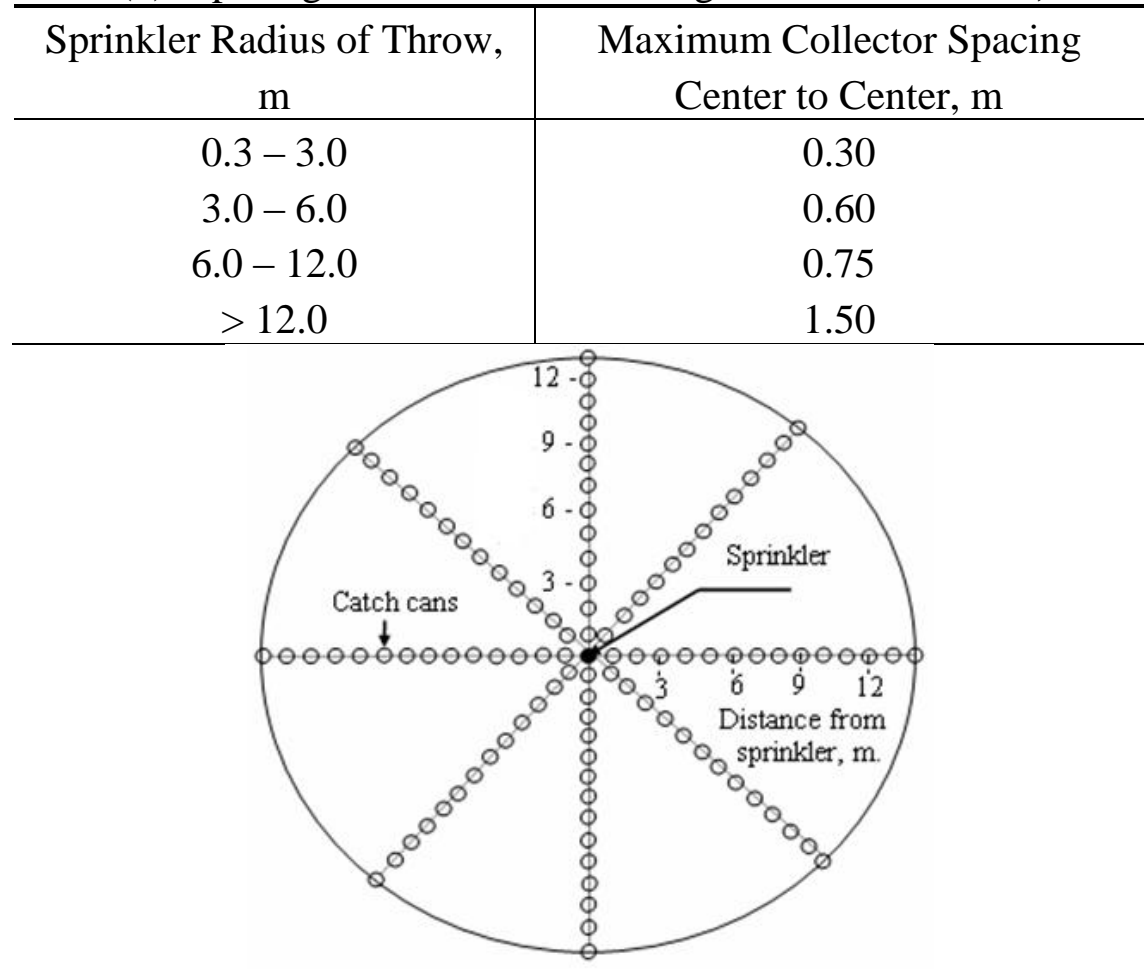

Figure (1). Schematic diagram representing distribution of catch cans.

The impact and rotating sprinklers were evaluated at different levels of operating pressure $(100,150,200,250,300$ and $350 \mathrm{kPa})$, riser height 
$(1.0 \mathrm{~m})$ and combination of trajectory angles $\left(20^{\circ}, 25^{\circ}, 30^{\circ}\right.$ and $\left.35^{\circ}\right)$ for rotating sprinkler under Egyptian conditions as shown in Table (2).

Table (2): Combination of trajectory angles for tested rotating sprinkler.

\begin{tabular}{ccccc}
\hline Set & 0 & 1 & 2 & 4 \\
\hline Angles $\boldsymbol{\theta}_{1}^{\circ} / \boldsymbol{\theta}_{2}^{\circ}$ & 20 & 25 & 30 & 35 \\
\hline 20 & 20,20 & 25,20 & 30,20 & 35,20 \\
25 & - & 25,25 & 30,25 & 35,25 \\
30 & - & - & 30,30 & 35,30 \\
35 & - & - & - & 35,35 \\
\hline
\end{tabular}

$\theta_{1}, \theta_{2}$ : Nozzle angle.

Operating pressure was measured using a pressure gauge with attached pressure pitot tube. The measurement was conducted by centering the pressure needle in the jet $3 \mathrm{~mm}$ from the sprinkler nozzle and recording the highest observed pressure.

Flow rate of sprinkler was measured by connecting a flexible tube to the sprinkler nozzle and collecting known volume of water in a container over a specified period $(5 \mathrm{~min})$. The flow rate was calculated as:-

$$
Q=\frac{V}{t}
$$

where, $Q$ is the flow rate of sprinkler in $\mathrm{m}^{3} \mathrm{~h}^{-1}, V$ is the collecting water volume in $\mathrm{m}^{3}$ and $t$ is time of collecting water in $\mathrm{h}$.

Water application of individual sprinkler was collected by catch cans installed across the full circle of sprinkler under different treatments. The application rate of sprinkler was calculated as:-

$$
A=k \frac{Q}{a}
$$

where, $A$ is the application rate in $\mathrm{mm} \mathrm{h}^{-1}, Q$ is the flow rate of sprinkler in $\ell \min ^{-1}, a$ is the wetted area of sprinkler in $\mathrm{m}^{2}$ and $k$ : unit constant $\left(k=60.0\right.$ for $A$ in $\mathrm{mm} \mathrm{h}^{-1}, Q$ in $\ell \min ^{-1}$ and $a$ in $\left.\mathrm{m}^{2}\right)$.

The distribution uniformity $(D U, \%)$ was calculated by the following formula (Heermann et al., 1990):-

$$
D U=100 \frac{Z_{l q}}{Z_{a v}}
$$


where, $Z_{l q}$ is the average catch can depth in the low quarter of the field in $\mathrm{mm}$ and $Z_{a v}$ is the average catch can depth in the entire field in $\mathrm{mm}$.

Uniformity tests were conducted by placing several identical collectors in an equally spaced grid in the field around sprinkler. The amount of water caught in each can was measured and recorded and the coefficient of uniformity $(C U, \%)$ was calculated by the following equation, Christiansen (1942):-

$$
C U=100\left(1-\frac{\Sigma\left|X_{i}-\bar{X}\right|}{n \bar{X}}\right)
$$

where, $X_{i}$ is the individual catch can measurement in $\mathrm{mm}, \bar{X}$ : mean of catch can measurements in mm, $\Sigma$ is the summation of $n$ values, || is the absolute value and $n$ is the number of measuring collectors.

The computer software Catch-3D Utah State University Catch-3D (Allen, 1992) was used to estimate water application uniformity from catch-can testes. Contour maps were constructed to present water depths, water distribution for all treatments using SURFER program (Golden Software, 2000). The computer software was used to draw 3-dimentional curves for the water application patterns to determine the sprinkler spacing that achieves optimum performance.

\section{RESULTS AND DISCUSSION}

Water application rate

The effect of operating pressure on flow rate for impact sprinkler and rotating sprinkler, is presented in Figure (2). It is apparent that the flow rate from individual sprinkler was highly affected by operating pressure. The effect of operating pressure and combination of trajectory angles on the performance of rotating sprinkler has been investigated. The flow rate increased with the increased operating pressure for different sprinklers. When increasing operating pressure from 100 to $350 \mathrm{kPa}$, the flow rate for impact and rotating sprinkler increased from 0.80 to $1.55 \mathrm{~m}^{3} \mathrm{~h}^{-1}$ and 0.40 to $0.72 \mathrm{~m}^{3} \mathrm{~h}^{-1}$, respectively. The results indicated that the flow rate from individual sprinkler was highly affected by operating pressure. 


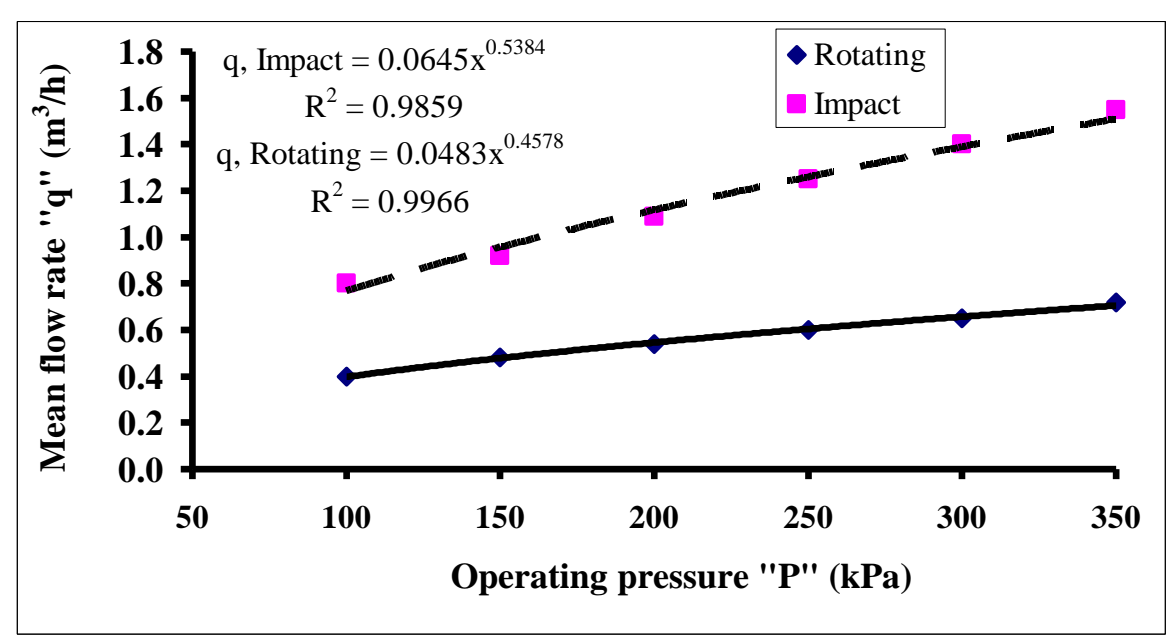

Figure (2). Relationship between operating pressure and flow rate for impact sprinkler and rotating sprinkler at trajectory angles $\left(20^{\circ}, 25^{\circ}\right)$.

The application rate increased with increasing operating pressure as shown in Table (3) for impact sprinkler. The application rate increased by $18.53 \%$ for impact sprinkler, when the operating pressure increased from 100 to $350 \mathrm{kPa}$ at riser height of $1.0 \mathrm{~m}$. it can be seen that the high application rate could be achieved by combination of high operating pressure with riser height is constant at $1.0 \mathrm{~m}$ for impact sprinkler. The rate of water application from a sprinkler is typically greater near the sprinkler and lower farther from the sprinkler.

Table (3): Average of flow rate, wetted area and application rate under different levels of operating pressure for impact sprinkler.

\begin{tabular}{cccc}
\hline $\begin{array}{c}\text { Operating } \\
\text { pressure } \\
(\mathrm{kPa})\end{array}$ & $\begin{array}{c}\text { Flow rate } \\
\left(\mathrm{m}^{3} / \mathrm{h}\right)\end{array}$ & $\begin{array}{c}\text { Wetted area } \\
\left(\mathrm{m}^{2}\right)\end{array}$ & $\begin{array}{c}\text { Application } \\
\text { rate }(\mathrm{mm} / \mathrm{h})\end{array}$ \\
\hline 100 & 0.80 & 114.93 & 6.93 \\
150 & 0.92 & 124.63 & 7.37 \\
200 & 1.09 & 138.51 & 7.87 \\
250 & 1.25 & 158.29 & 7.90 \\
300 & 1.40 & 170.79 & 8.20 \\
350 & 1.55 & 188.60 & 8.22 \\
\hline
\end{tabular}

The application rate increased with increasing operating pressure at the same combination of trajectory angles. When the operating pressure 
increased from 100 to $350 \mathrm{kPa}$ at combination of trajectory angles $\left(20^{\circ}\right.$, $20^{\circ}$ ), the application rate increased from 5.18 to $6.57 \mathrm{~mm} \mathrm{~h}^{-1}$. Similar trend was observed for all tested combination of trajectory angles but with different values. In addition, for all trajectory angle sets, the highest values of application rate were achieved at combination of trajectory angles $\left(20^{\circ}, 20^{\circ}\right)$ with operating pressure of $350 \mathrm{kPa}$ as shown in Figure (3).

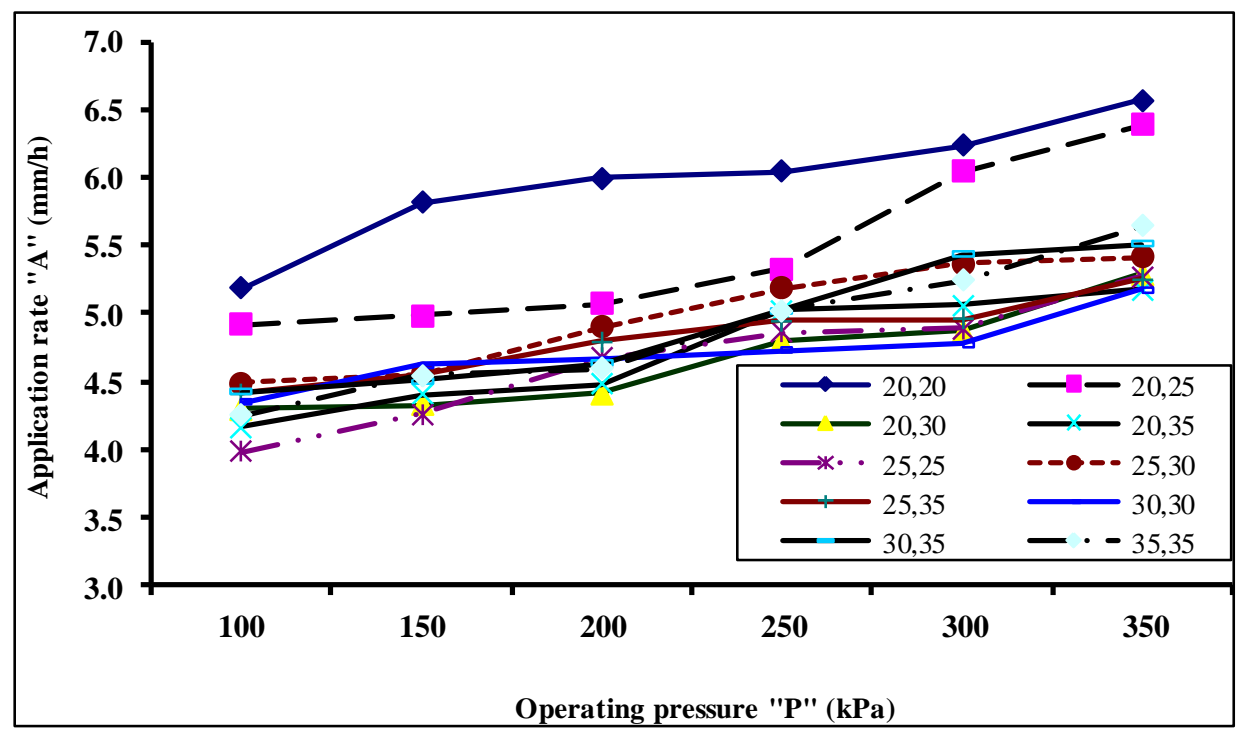

Figure (3). Relationship between operating pressure and application rate at different combination of trajectory angles for rotating sprinkler under tested pressure ranges.

It can be concluded that the application rate increased by increasing operating pressure under the same combination of trajectory angles. This may be due to increase of water discharge. Also, application rate decreased by increasing combination of trajectory angles to specific level and it increased again this may be due to decrease of wetted area. Consequently, the high application rate could be achieved by combination of high operating pressure with low combination of trajectory angles.

\section{Water application uniformity for impact sprinkler}

The uniformity of application is considered as a primary concern in the sprinkler irrigation design procedure. The coefficient of uniformity $(C U)$ and distribution uniformity $(D U)$ were determined at level $1.0 \mathrm{~m}$ riser 
height and different operating pressures. Figure (4) shows the relationship between water application uniformity and operating pressure at $1.0 \mathrm{~m}$ riser height. The $C U$ and $D U$ increased with increased operating pressure until its maximum at $200 \mathrm{kPa}$, but at operating pressures higher than $200 \mathrm{kPa}$, the $C U$ and $D U$ decreased again. It can be seen that increasing of operating pressure from 100 to $200 \mathrm{kPa}$ at riser height 1.0 $\mathrm{m}$, the $C U$ and $D U$ values increased from $80.05 \%$ to $90.55 \%$ and from $51.30 \%$ to $68.10 \%$, respectively. In contract, when the operating pressure increased from 200 to $350 \mathrm{kPa}$, the $C U$ and $D U$ values decreased from $90.55 \%$ to $85.5 \%$ and from $68.10 \%$ to $64.05 \%$, respectively for impact sprinkler.

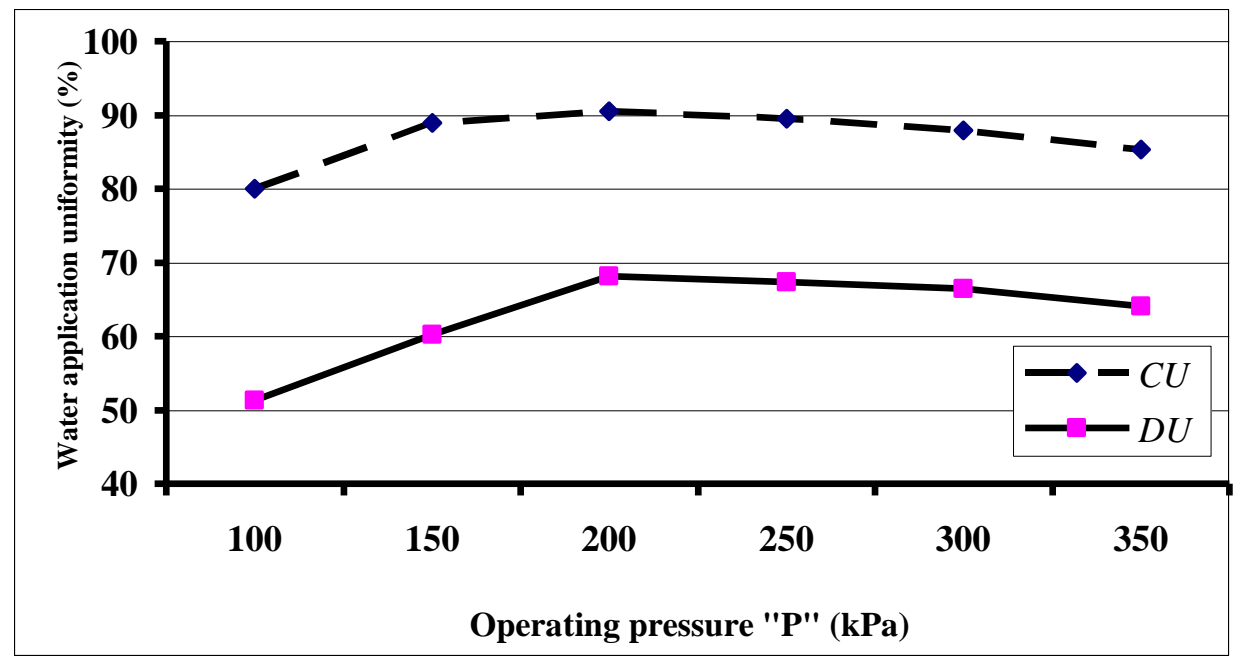

Figure (4). Relationship between operating pressure and water application uniformity for the impact sprinkler.

The decrease of $C U$ and $D U$ at low and high operating pressures may be due to non-uniform water distribution. Thus, at low operating pressure level, the water jet did not break up easily and large water drops were formed and fall close to the sprinkler and sprinkler throw was reduced. Also, at high operating pressure level, the jet broke up too much and small water drops were produced which were easily to be blown and threw away from the sprinkler. 
The results indicated that, there is a parallel trend of $C U$ and $D U$ the highest values of $C U$ and $D U$ were achieved with operating pressure of $200 \mathrm{kPa}$ and riser height of $1.0 \mathrm{~m}$. This means that the more improved water application uniformity could be achieved under previously mentioned operating pressure and riser height.

\section{Water application uniformity for rotating sprinkler.}

The water application uniformity was evaluated by investigating the effect of operating pressure and combination of trajectory angles on coefficient of uniformity $(C U)$ and distribution uniformity $(D U)$. Figures (5 and 6) show the relationship between $C U, D U$ and operating pressure at different combinations of trajectory angles. It can be seen that the $C U$ and $D U$ increased by increasing of operating pressure from 100 to 200 $\mathrm{kPa}$ and decreased by increasing of operating pressure from 200 to 350 $\mathrm{kPa}$ with different combinations of trajectory angles.

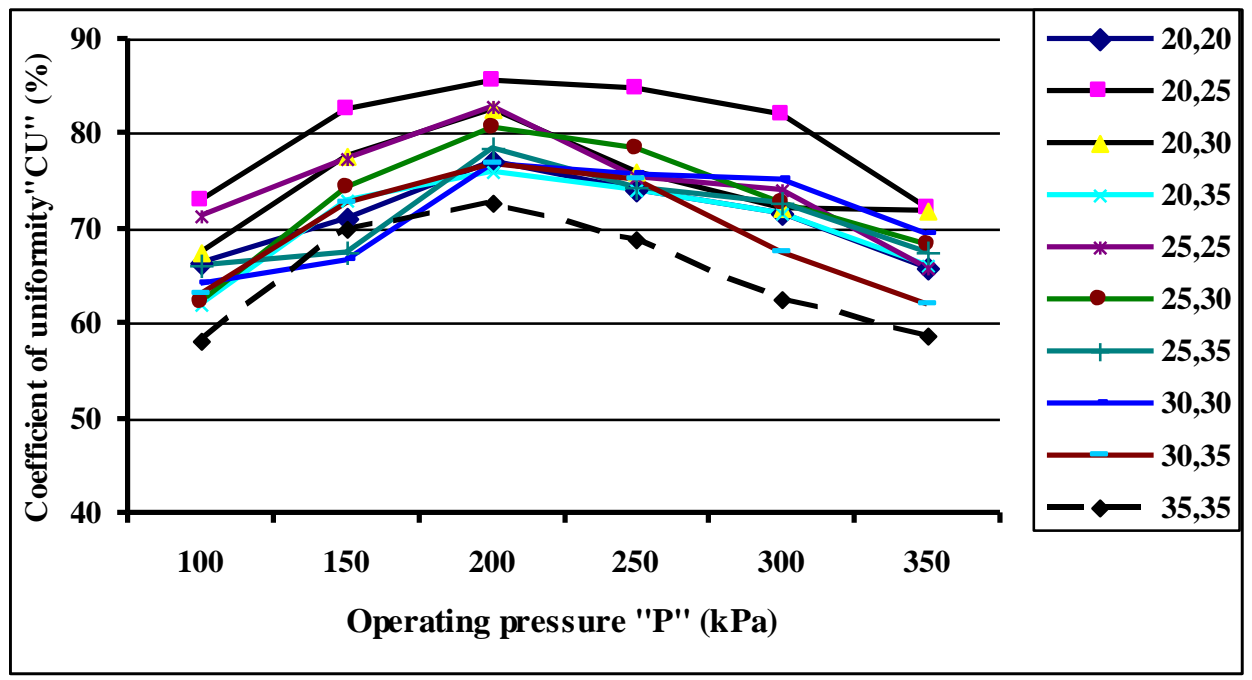

Figure (5). Relationship between operating pressure and coefficient of uniformity at different combination of trajectory angles for rotating sprinkler.

The $C U$ and $D U$ values increased from 72.95 to $85.60 \%$ and from 48.39 to $60.50 \%$, respectively for rotating sprinkler, when operating pressure increased from 100 to $200 \mathrm{kPa}$ at combination of trajectory angles $\left(20^{\circ}\right.$, $25^{\circ}$ ). Also, the operating pressure increased from 200 to $350 \mathrm{kPa}$, the $C U$ 
and $D U$ values decreased from 85.60 to $72.15 \%$ and from 60.50 to 45.05 $\%$ at combination of trajectory angles $\left(20^{\circ}, 25^{\circ}\right)$. The results indicated that the highest values of $C U$ and $D U$ were achieved at operating pressure of $200 \mathrm{kPa}$ and combination of trajectory angles $\left(20^{\circ}, 25^{\circ}\right)$. The corresponds values were $85.60 \%$ and $60.50 \%$, respectively. Also, the lowest value of $C U$ and $D U$ were $58.16 \%$ and $30.05 \%$, respectively at operating pressure of $100 \mathrm{kPa}$ and combination of trajectory angles $\left(20^{\circ}\right.$, $25^{\circ}$.

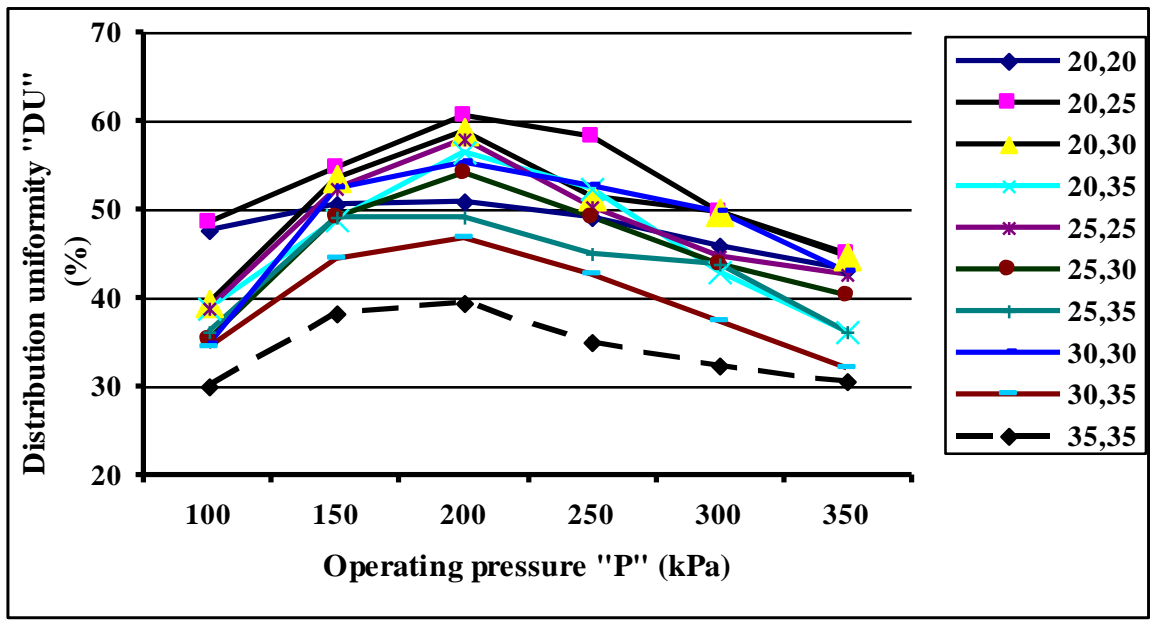

Figure (6). Relationship between operating pressure and distribution uniformity at different combination of trajectory angles for rotating sprinkler.

The decrease of coefficient of uniformity and distribution uniformity at low and high operating pressures with all tested combination of trajectory angles could be due to non-uniform water distribution. Thus, at low operating pressure level, long water drops were formed and fall close to the sprinkler and sprinkler throw is reduced. Also, at high operating pressure level, small water drops were produced which was be easily to be blown and thrown away from the sprinkler. Therefore, it can be concluded that to achieve high coefficient of uniformity and distribution uniformity operating pressure of $200 \mathrm{kPa}$ and combination of trajectory angles $\left(20^{\circ}, 25^{\circ}\right)$ are recommended. 
In general, for all tested operating pressures and riser height, the $C U$ increased with increased operating pressure until its maximum at 200 $\mathrm{kPa}$, but the operating pressure higher than $200 \mathrm{kPa}$, the $C U$ decreased again. Also, the impact sprinkler improved water application uniformity compared with rotating sprinkler under all tested levels of operating pressure and riser height as shown in Figure (7). Thus may be due to the manufacturing reliability of impact sprinkler. Based on the obtained results, it can be concluded that, the high water application uniformity of impact sprinkler and rotating sprinkler can be achieved at operating pressure of $200 \mathrm{kPa}$ and combination of trajectory angles $\left(20^{\circ}, 25^{\circ}\right)$ at riser height of $1.0 \mathrm{~m}$.

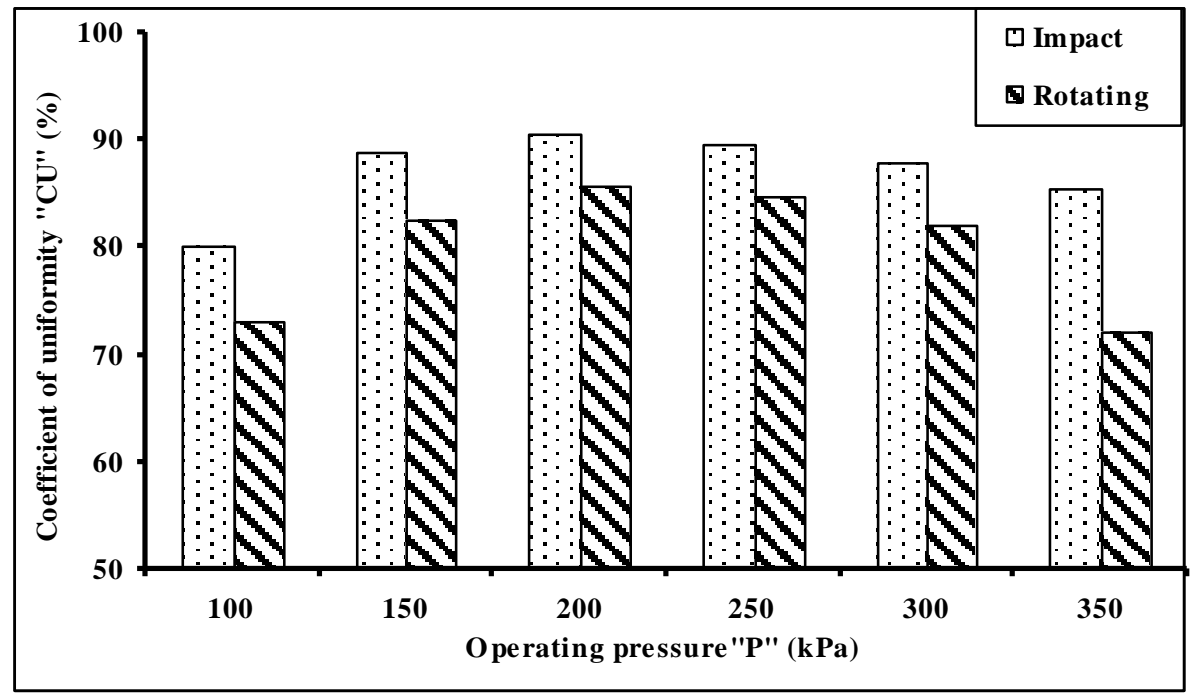

Figure (7). Relationship between operating pressure and coefficient of uniformity at different sprinklers.

Distribution uniformity for different sprinklers at different overlapping

The spacing of spray sprinkler is a limited factor to design the sprinkler systems. Therefore, it is relevant to predict sprinkler spacing that achieves optimum water distribution. Distribution uniformity $(D U)$ is considered as a basic indicator for water application uniformity for each sprinkler and it is affected by overlapping between sprinklers. The experimental data related to impact sprinkler and rotating sprinkler were 
simulated using also computer software (Catch-3D) and (SURFER program) at operating pressure ranged from $100 \mathrm{kPa}$ to $350 \mathrm{kPa}$, combination of trajectory angles $\left(20^{\circ}, 25^{\circ}, 30^{\circ}\right.$ and $\left.35^{\circ}\right)$, riser height 1.0 $\mathrm{m}$, overlap percentage ranged from $40 \%$ to $100 \%$ and wind speed ranged from 0.40 to $1.82 \mathrm{~m} \mathrm{~s}^{-1}$.

The results showed that the water distribution profiles of single sprinkler were affected by overlapping between sprinklers. It is clear that the overlapping improved water distribution uniformity. The $D U$ for individual sprinkler at operating of $200 \mathrm{kPa}$ with combination of trajectory angles $\left(20^{\circ}, 25^{\circ}\right)$ and riser height of $1.0 \mathrm{~m}$, sprinkler were $68.10 \%$ and $60.50 \%$ and the corresponding values at overlap percentage $60 \%$ were $87.09 \%$ and $80.92 \%$ for impact and rotating sprinkler with combination of trajectory angles $\left(20^{\circ}, 25^{\circ}\right)$, respectively as shown in Figures ( 8 and 9 ). These results are in agreement with those reported by Keller and Bliesner, (2000), and Hegazi et al. (2007). This means that the overlapping improved distribution uniformity by $18.99 \%$ and 20.42 $\%$ for impact and rotating sprinkler, respectively. Consequently, the $D U$ was in excellent according to ITRC (1991) and Schwankl et al. (2003) for different sprinklers at overlapped percentage of $60 \%$.

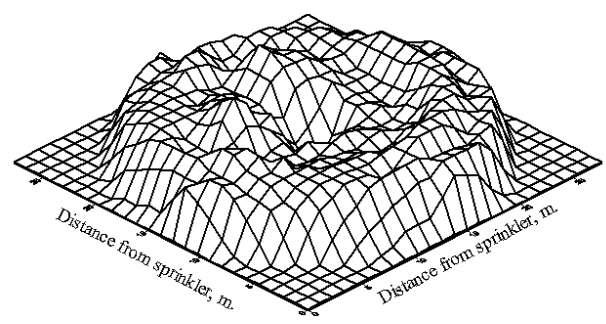

$$
D U=68.10 \%
$$

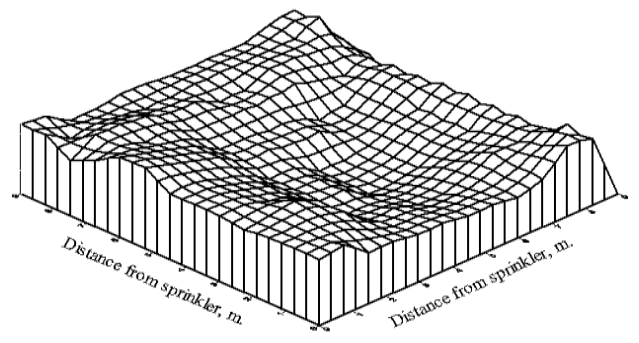

$$
D U=87.09 \%
$$

a - Original data from a single sprinkler. b - Overlap pattern for $60 \%$

(Simulated).

Figure (8): Water distribution profiles at operating pressure $200 \mathrm{kPa}$ for impact sprinkler. 


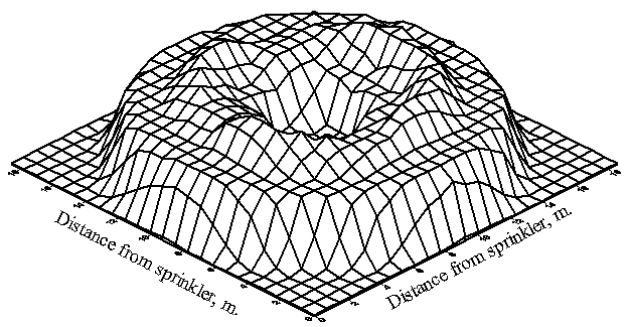

$D U=60.50 \%$

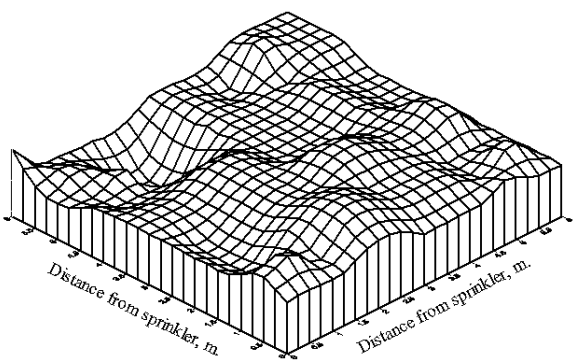

$D U=80.92 \%$

a - Original data from a single sprinkler. b - Overlap pattern for $60 \%$ (Simulated).

Figure (9). Water distribution profiles at operating pressures $200 \mathrm{kPa}$ and trajectory angles of $\left(20^{\circ}, 25^{\circ}\right)$ for the rotating sprinkler.

\section{CONCLUSION}

It has been concluded that the performance of two types of impact sprinkler and rotating sprinkler was affected by operating pressures and combination of trajectory angles. The results led to the following concluded points.

1- Flow rate and application rate were increased by increasing operating pressure for impact sprinkler and rotating sprinkler.

2- The high of water application uniformity was achieved at operating pressure of $200 \mathrm{kPa}$ for both types of sprinklers. And combination of trajectory angles $\left(20^{\circ}, 25^{\circ}\right)$.

3- Optimal spacing between sprinklers was found to be overlap percentage $60 \%$ from wetted diameter for both types of sprinklers (Simulated data).

\section{REFERENCES}

Aboamera, M. and H. Sourell (2003). Characteristics of water distribution and irrigation intensity for floppy sprinklers. The $11^{\text {th }}$ Annual Conference of Misr Society of Agricultural Engineering, Egypt, 15-16 Oct., 20(4): 937 - 948. 
Allen, R. G. (1992). Catch 3D-software sprinkler-pattern overlap program, Version 4.60. Biological and Irrigation Engineering Department, Utah State University, Logan, Man. PP: 16.

Amer, K. H. (2006). Water distribution uniformity as affected by sprinkler performance. Misr Journal of Agricultural Engineering, Egypt, 23(1): 82 - 95.

ASABE S398.1 (2006). Procedure for sprinkler testing and performance reporting. ASABE, 932 - 935.

Awady, M. N. and A. H. Gomaa (1996). A sprinkler irrigation-head developed for simplicity and low-pressure operation. Misr Journal of Agricultural Engineering, Cairo University Irrigation Conference, 3 - 4 April: 119 - 129.

Ascough, G. W. and G. A. Kiker (2002). The effect of irrigation uniformity on irrigation water requirements. Water SA, 28(2): 235 $-241$.

Badr, A. E. (1992). Water distribution from different sprinkler arrangements and its effect on yield (under fixed sprinkler irrigation system). Misr Journal of Agricultural Engineering, Egypt, 9(3): 398 - 419.

Christiansen, J. E. (1942). Irrigation by sprinkler. Bulletin 670 . California Agricultural Experiment Station. University of California. Berkeley, California.

Dukes, M. D.; M. B. Haley and S. A. Hanks (2006). Sprinkler irrigation and soil moisture uniformity. the $27^{\text {th }}$ Annual International Irrigation Show San Antonio, TX.

El-Ansary, M. Y.; A. M. El-Gindy; M. A. Awad and E. A. Wasif (2003). Evaluation of the alternate sets management of sprinkler irrigation. The $11^{\text {th }}$ Annual Conference of Misr Society of Agricultural Engineering, Egypt, 15-16 Oct., 20(4): 236 - 250. 
Golden Software (2000). Contouring and 3D-surface mapping for scientists and engineers Version 7. Golden Software, Inc., www. goldensoftware. com.

Heermann, D. F.; W. W. Wallender and G. M. Bos (1990). Irrigation efficiency and uniformity. (C. F. Hoffman, G. J., Howell, T. A., Solomon, K. H. (Eds.), Management of Farm Irrigation Systems. ASAE, St. Joseph, MI. 125 - 149).

Hegazi, M.; K. H. Amer and H. Moghazy (2007). Sprinkler irrigation systems layout based on water distribution pattern. Misr Journal of Agricultural Engineering, Egypt, 24(2): 360 - 377.

ITRC (1991). Landscape water management principles, Version 1.01, Irrigation Training and Research Center, Cal Poly State University, San Luis Obispo, California: 140P. (C.f.).

Keller, J. and R. D. Bliesner (2000). Sprinkler and trickle irrigation. Van Nostrand, Reinhold, New York. PP: 652.

Kincaid, D. C.; K. H. Solomon and J. C. Oliphant, (1996). Drop size distributions for irrigations sprinklers. Transactions of the ASAE, 39(3): 839 - 845.

Schwankl, L. J.; D. A. Shaw; M. A. Harivandi and R. L. Snyder (2003). Evaluating turfgrass sprinkler irrigation system, Coop. Ext., University of California, Division Agricultural and Nat. Resources, Leaflet 21503: 18p.

Seginer, I.; D. Kantz and D. Nir (1991). The distortion by wind of the distribution patterns of single sprinklers. Agricultural Water Management, USA, 19: 341 - 359.

Tarjuelo, J. M.; J. Montero; F. T. Honrubia; J. J. Ortiz and J. F. Ortega (1999). Analysis of uniformity of sprinkler irrigation in a semi-arid area. Agricultural Water Management, USA, 40: 315 331. 


\section{الملخص العربي}

تقيم أداء الرشاش التصادمى والدوار على أساس بيانات علب التجميع عبد التواب متولى ابراهيم زيدان* و أحمد فتحى محمد خضر *

الهدف من هذه الدراسة هو تقييم أداء نوعين من الرشاشات، الرشاش التصادمى (التصرف

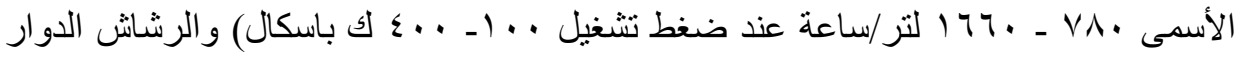

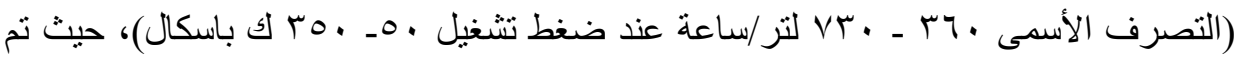

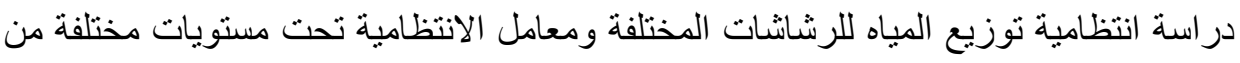

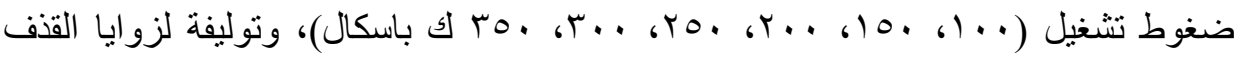

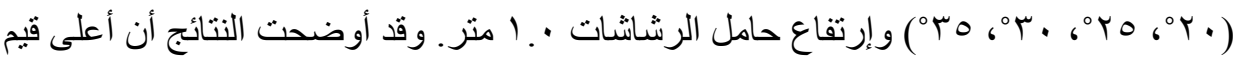

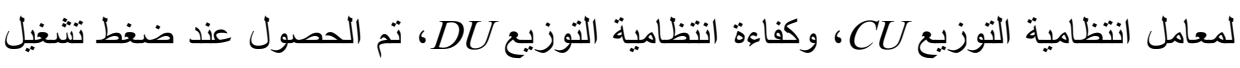

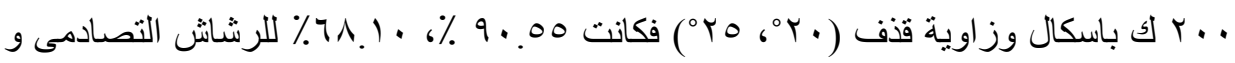

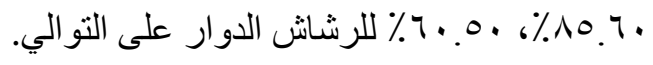

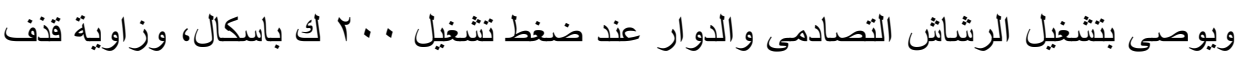

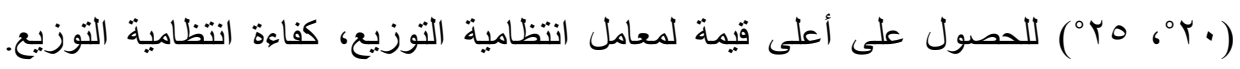
وللحصول على نسبة تداخل لتحديد البعد المناسب بين الرشاثنات وتم تمثيل البيانات الفردية

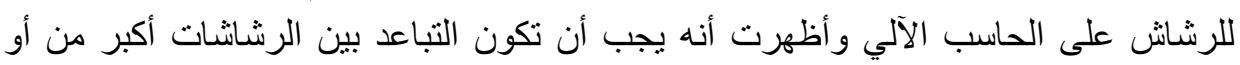

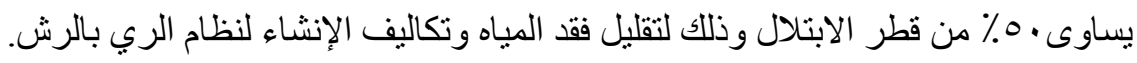

* مدرس بقسم الهندسة الزراعية ـ كلية الزراعـة - جامعسـة الزقازيق.

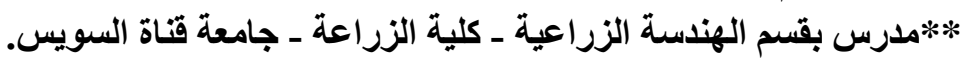

